\title{
Literacy Culture Strengthening Programs to Stimulate Reading Interest for Children at Early Age
}

\author{
Mila Faila Shofa ${ }^{1}$, M Heri Yuli Setyawan ${ }^{2}$ \\ 1PIAUD FITK IAIN Surakarta \\ 2PGPAUD Unisri
}

\section{ABSTRACT}

This research aims are to describe the concept of literacy culture on children at early age and to describe the implementation of literacy culture strengthening program on children at early age enrolled at PAUD Inklusi Saymara. The research method used is descriptive qualitative, and the research is conducted at PAUD Inklusi Saymara Kartasura, Sukoharjo, Jawa Tengah.

The research results find that the literacy culture program is important to be implemented from early childhood, starting in the family circle and continued to school age. School is an environment that has determining role in forming children's reading interest. The programs implemented at PAUD Inklusi Saymara include "one day one story" program, in which the teacher will tell stories for the students via various media. The activity of book reading in compelling way will inspire children that reading is fun, and it will stimulate children's reading interest. The second program is strengthening reading interest based on library. Library holds important role in fostering and developing awareness in reading. The third program is stimulating children's skills in reading and writing through playful activities. The program to stimulate children's reading and writing skills is according to the phases of reading and writing development on 4/6-year-old children. The last program is visiting bookstore to introduce and familiarize books for kids and build literacy culture from early childhood. Through the programs to strengthen literacy culture at PAUD Inklusi Saymara, it is proven that the children's reading interest improves significantly.

\section{KEY WORDS}

program, literacy culture, reading interest, early childhood

CORRESPONDING AUTHOR:

email: milashofa34@gmail.com

Manuscript submitted June 28, 2018; accepted Agustus 18,

2018.

\section{INTRODUCTION}

In today's digital era, literacy culture continuously diminishes in Indonesia. People, including children, prefers spending most of their time to play gadget and watch TV rather than reading books. The Central Bureau of Statistics states that Indonesian children
Copyright: (02018 This is an open access article under the terms of the Creative Commons Attribution License, which permits unrestricted use, distribution, and reproduction in any medium, provided the original author and source are credited.

spend the average time of 300 minutes per day to watch television. This number is higher if compared to Australian children who spend 150 minutes per day or American children who spend 100 minutes per day, or even Canadian children who only spend 60 minutes per day (Republika, 2015). Furthermore, the 


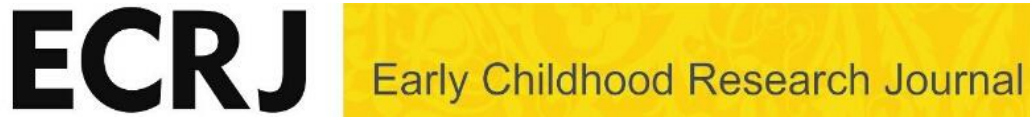

literacy level in Indonesia was only at 64 out of the total 65 surveyed countries. Another depressing fact is that the Indonesian students' reading level only ranked 57 th out of 65 countries (Republika, 2015). It seems, Indonesian people have less awareness of the importance of reading habit, do not the habit to do so, and lack of facility to support reading interest.

The development of a country is highly influenced by level of knowledge and intelligence of its citizens. Level of intelligence and knowledge could be seen through the extent of received information both in written and verbal. Therefore, literacy culture determines the quality of a country's civilization. Literacy culture is a crucial problem that a country needs to resolve. A country could not improve this culture without having a cooperation with the community in general. Therefore, it is important to foster literacy culture as early as possible and implemented within the family, school, and community unit.

Literacy culture should be started from home and as early as possible. Family is the very first environment experienced by children and it is the beginning of their habits. Family unit should be aware of literacy habit to form scientific mindset. Recently, the government attempts to produce more families with high reading awareness through Directorate of Family Education Development (Direktorat Pembinaan Pendidikan Keluarga), General Directorate of Early Childhood and Community Education (Direktorat Jenderal Pendidikan Anak Usia Dini dan Pendidikan Masyarakat), and Ministry of Education and
Culture (Kementerian Pendidikan dan Kebudayaan). Parents could motivate children's reading interest through literacy culture by implementing simple activities such as reading stories/fairy tales before sleeping, which could definitely generate positive habit of reading interest for children. Parents could also give example of "literacy exemplary" by always spending enough time to read with their children at home. Infrastructure and facility also helps in encouraging reading interest for children, in which families are hoped to have family library where children have access to read more books at home.

In addition to home, improving reading interest should be maintained at school. School is the perfect environment for this and highly influential for furthering children's reading interest. School literacy movement is a participative effort or activity by involving all school members (students, teachers, principals, staffs, school supervisor, school committee, and parents), academicians, publishers, mass media, and community (public figure representing exemplary behavior, business, etc.). Fostering reading interest is not an instant effort, it needs time; therefore, this effort should start from children at early age (PAUD).

Pendidikan anak usia dini (PAUD) or early childhood education program is education program established to develop character, knowledge, and skills that serve as the foundation as well as for the complete development of self, according to the principle of early education and education for life. PAUD is educational service for children of 0-6 years old, in which the main purpose of PAUD 
is to build the foundation of character development, growth stimulation, and fostering positive habits including literacy routine and culture. Early childhood is golden age, therefore, early childhood education is a part of fundamental education and will determine the children's subsequent growth. Teaching children at early age can be likened to building foundation of a house. If the foundation is strong, other parts of the house will be strong, and vice versa.

Fostering children's reading interest at early age should also pay attention to early childhood education characteristics. It is conducted through choosing suitable reading materials according to age range, and selecting books with interesting visages and pictures could also help developing their reading interest. Furthermore, comfortable and intriguing nuance to read could also motivate their interest. Through this article, the writer aims to describe the program to strengthen literacy culture implemented at PAUD Inklusi Saymara Kartasura, Sukoharjo, Jawa Tengah with the expectation that it will provide enough instances of literacy culture programs to improve children's reading interest at early age.

\section{RESEARCH METHOD}

The method used for this research is descriptive qualitative. Bogdan and Taylor in Moleong (2000) defined qualitative research as a research procedure that generates descriptive data in the form of written or verbal words and observed behaviors. Qualitative research generates findings that cannot be achieved through statistical procedures or quantification methods (Ghoni, 2017). The research is conducted at PAUD Inklusi Saymara Kartasura, Sukoharjo, Jawa Tengah during the 2017/2018 academic year. The data collection techniques in this research are done using observation, interview, and documentation.

The writer conducted an observation to garner direct demonstration of literacy culture strengthening program at school. The observation focused on learning process, supporting programs for literacy culture and children's reading interest at PAUD Inklusi Saymara. The interview was performed between researcher and teachers, principal, and students. The interview with teachers or faculty members was conducted to acquire information regarding the learning process to develop children's reading interest; interview with the principal was to gain information regarding programs of literacy culture to develop children's reading interest; and the interview with students was done to understand their reading interest at school. Documentation is used to acquire data at school. It is in the form of recording during learning process and the implementation of literacy culture strengthening program at school.

To ensure the legitimacy and validity of data that are collected and recorded in the research, the research chooses and determines proper methods to develop the validity of acquired data. This research employs data source triangulation method to test the data validity. Data source triangulation is conducted by (1) comparing observation result about learning and literacy 


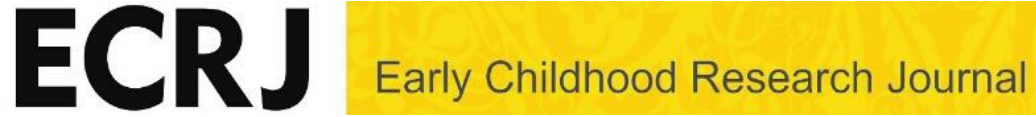

culture program to the interview with teachers, principal, and students; (2) comparing the interview with teachers, principal, and students; and (3) comparing the interview result with related documents.

The research data are analyzed using descriptive qualitative approach with interactive analysis consisting of data reduction, data presentation, and conclusion. Data reduction is performed through data selection, data simplification, and rough data transformation from the observation and interview result about literacy culture at PAUD Inklusi Saymara. The data presentation includes organized observation and interview result about literacy culture and reading interest of students at PAUD Inklusi Saymara. Making conclusion is a part of decision making process with the support of valid and consistent evidence found by the researcher.

\section{RESULTS AND DISCUSSION}

\section{A. Literacy Culture}

The term literacy expands from time to time, literacy itself cannot be merely defined as the ability to read and write as it has broad definition. Permatasari (2015) explained that there are many types of literacy, including computer literacy, media literacy, technology literacy, economy literacy, information literacy, and even moral literacy. Surangga (2017) mentions some components of literacy in the following section:

1. Early Literacy (Clay, 2001) is the ability to listen and understand verbal language, and communicate through pictures and verbal language, which is shaped through their experience in interacting with his/her social environment at home. Students' experience in communicating with mother language becomes the foundation of basic literacy development.

2. Basic Literacy is the ability to listen, talk, write, and count related to analysis ability of calculation, perceiving information, communication, and describing information (drawing) based on comprehension and personal decision making.

3. Library Literacy is to provide an understanding of how to distinguish fiction and nonfiction books, utilizing reference and periodical collection, understanding Dewey Decimal System as a classification of knowledge to ease the use of library, understanding the use of catalog and indexing so that we have the information to finish writing articles, research, work, or solving problems.

4. Media Literacy is the ability to understand different types of media such as print media, electronic media (i.e., radio, television), digital media (i.e., internet), and understand the purpose of its use.

5. Technology Literacy is the ability to understand the entire equipment of a technology including hardware, software, and the ethics and etiquettes in utilizing technology.

6. Visual Literacy is the advanced understanding of media literacy and technology literacy, which develops the learning ability and needs by utilizing visual and audiovisual materials with critical and honorable thinking. 


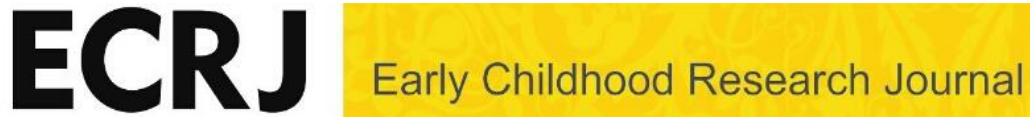

Literacy does not only focus on the ability to read and write, it also means one should be knowledgeable in all forms of information, technology, media, moral, and even politics. In this research, however, literacy focuses more on the ability and skills in reading during early literacy and basic literacy according to the literacy skills of children at early age.

One way to improve the civilization of a region or country is through education. High quality education becomes an important asset in the midst of increasingly uncompromising global competition. One effort to create quality education is through improving literacy culture (reading and writing). Dr. Roger Farr (1984) in Surangga (2017) mentioned that "reading is the heart of education" or in other words, reading is a way to generate progressive education. Most progress in education depends on the ability and awareness of literacy. Literacy culture imprinted within young generation could influence success during education level and social life. The government through the Ministry of Education and Culture in the end of 2015 founded several breakthroughs in the form of Gerakan Literasi Bangsa (GLB) or National Literacy Movement. This movement aims to foster youngsters' character through literacy culture (reading and writing). This policy was reinforced by Regulation of Ministry of Education and Culture No. 23 of 2015 regarding the policy for 15 minutes of reading time before lesson starts.

Building a culture means fostering habit, which is also similar to developing literacy culture that is not as easy as falling off of a log. Literacy culture cannot be built in one as it needs habituation from an early age. Similar to building character, nurturing habits should be done through familiarization and examples. There are many forms of activities to foster habits to inspire literacy culture movement at school, for example by placing books as close as possible to children, accessibility of library books including the availability of reading corners, reading books done by teachers, and so on. The availability of books according to the children's characteristics and needs could also buttress the success of this program. Exemplary actions from all faculty members is the determining factor of realizing literacy culture at school. Teachers, principals, and school guards who are familiar with books will create conducive literacy culture at school. Another decisive factor, which is also very important, is the willingness of all faculty members. When students witness their teachers read, unconsciously they will also try to imitate the teachers. This program requires commitment and struggle from all parties to realize literacy culture movement at school. Without these efforts, literacy culture programs will be in vain and forgotten.

Commencing literacy culture at early age becomes the focus of the government's efforts, especially from the Ministry of Education and Culture in the beginning of 2018 by launching GERNAS BAKU or Gerakan Nasional Orang Tua Membacakan Buku (National Movement of Parents Reading Books). This movement begins in February with the main agenda of socialization and campaign for Gernas Baku, Gernas Baku seminar and the inauguration of bunda PAUD and the head of Himpaudi as the driving 


\section{ECRJ}

agents of gernas baku. In March, the movement continues with agendas on book donation and the provision of reading corners at various PAUD, provision of children and parents' books in families and bunda PAUD/Head of related organizations/public figure reading books at various PAUD. April is for parenting month and evaluation, which is concluded with soft launching and the complete implementation of gernas baku in Indonesia on Saturday, May 5th 2018.

Gernas Baku launched by the government is hoped to be a refreshing program for strengthening literacy culture in schools especially for children at early age. It is undeniable that the culture of reading books for kids could foster reading culture from early age. Harvey Perlman and Helen Raikes, two lecturers at University of Nebraska conducted a "Research in Early Education and Partnership". The research was conducted on children within 8-and-below-year-old age group before they were enrolled at school in China and Turkey. Their findings were interesting to be studied further, in which there was a significant different between children who had experienced ECE (Early Childhood Education) period with those who did not, in terms of literacy. Children who had no prior introduction or education when they were young had low level of total literacy, and vice versa (Mursyid, 2016).

Activities such as reading books and storytelling among kids could become a starting point to foster children's reading habit. After being interested in fairy tales, children are expected to further nurture their interest in books. It can start from story books that they are familiar with, and expand to other books such as common knowledge, science, religion, and so on. Indirectly, the habit to listen to stories will continue to interest in reading more books.

\section{B. Reading Interest}

The main problem in Indonesia nowadays is not illiteracy because the phenomenon has decreased significantly. The most pressing problem is literate people who do not want to read. This problem occurs because there is no motivation or stimulus of reading interest, lack of facilities, and the development of technology that becomes the threat for decreasing reading interest. Theoretically, there is a positive correlation between reading interest and reading habit and reading ability. Low reading interest among people affects low reading habit, which will also influences low reading ability. This is what happens in Indonesia today.

Reading is one of four reading skills; they are speaking, listening, reading, and writing. These four skills are interrelated. Listening and reading are receptive language, while speaking and writing are expressive language, in which speaking and writing ability will not develop well if someone does not have good listening and reading ability. Theoretically, reading ability influences language skills in general.

Since reading is an important skill to acquire, it should be fostered as early as possible. The purpose of children's reading ability according to Marrow in Dhieni (2006) could be explained in the following section: 


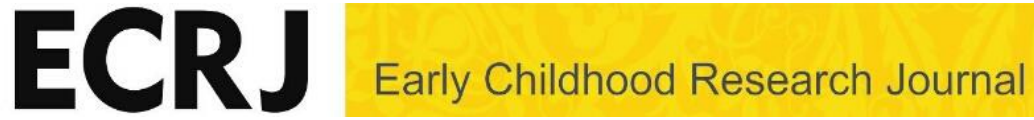

1. The development of positive reaction towards reading

Positive reaction towards books and reading activity could be improved through strategies in creating environment flourished with literacy culture, creating fun and fascinating reading stories activity by using interesting technique and facility, and designing independent reading and writing activity that will inspire children during the activity of their own selection.

2. The development of concept about books and text comprehension

Concepts about books include the concept of books' functions for reading, parts of books, how to open, turn pages, book contents including texts and pictures, the relation of pictures and texts, the meaning of title and the beginning of text on each page.

Encouraging children's reading interest should also focus to the stages of reading development on children. According to Cochrane Efal as cited by Dhieni (2006), basic development of reading on 4-6-year-old children occurs in five stages; they are:

a. Magical stage

b. Self-concept stage

Bridging reading stage

d. Sake-off reader stage

e. Independent reader stage

During the magical stage, we can see from how children pretend as if they are reading books, while in fact they have not had the ability to. Self-concept stage can be seen from children's activity that shows their interest in books, asking for their parents or teachers to read books. On this stage, the emergence of children's interest on books is a form of self- concept formation on children. Generally, children prefer books with pictures, which will support reading development on bridging reading stage. The phase of introducing books can be seen from children who have started to recognize letters, spell letters to form syllables, syllables to words and words to sentences. After the child recognizes the final stage of reading, the child's reading ability is considered as fluent reading stage where the child can read the text independently and fluently.

According to the stage of reading development on children, before teaching kids about the basic abilities of reading or readiness to read should be mastered by children. These basic abilities are needed for children to succeed in reading and writing. The basic abilities to write that children need to master include:

a. Ability to distinguish auditors

b. Ability to discriminate visual markers

c. Ability to make relation between sound and symbol

d. Motoric perceptual skills

e. Verbal language skills

f. Creating background for experience

g. Picture interpretation

h. Progression from left to right

i. Ability to compose words

j. Use of oral language

k. Introduction to seeing words

I. Lateralization

m. Movement coordination

Reading skill is a complex ability, which means that the success of children's reading skill development is influenced by many 


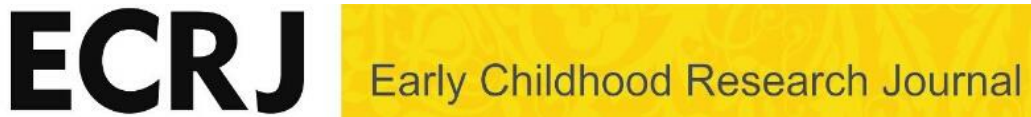

factors. Anderson in Dhieni (2006) stated that motivation, environment, family and teachers are factors in determining the development of children's reading interest. The following part will describe these factors in detail.

1) Motivation

Motivation becomes an encouraging factor for children to read. Someone with strong motivation will read willingly without even being compelled to do so, and conversely, someone without the motivation will not want to read. The motivation for reading interest is important because it will also lead to good learning skills. Some methods to motivate students to read include providing fascinating reading materials based on their needs and interest, conveying the importance and advantages of reading to children, and teachers serve as the catalyst of motivation and interest as well as role model for their students.

2) Environment

Environment has strong influence on children's reading interest such as through the availability of adequate facilities and supportive environment. The family environment plays an important role such as providing reading materials at home, exemplifying literacy from parents as often as possible to make children love reading.

3) Reading materials

Reading interest and reading ability are also influenced by reading materials. Complex and difficult reading material could discourage someone to read. Related to this aspect, there are some factors that we need to focus on: topic or content and the readability of a reading material. Bromley in
Dhieni (2006) stated that reading material for children should be critical materials and media in teaching communication effectively. Children should be introduced to various reading topics that it will enrich their knowledge. However, the selected topics should also match children's interest such as reading materials about dinosaurs, animals, vehicle, and so on.

\section{Programs for Strengthening Literacy Culture in Fostering Reading Interest of Children at Early Age at PAUD Inklusi \\ Saymara Kartasura}

PAUD Inklusi Saymara is an integrated Early Childhood Education institution, in which it also provides facilities in daycare or TPA (Taman Pengasuhan Anak), playgroup or KB (Kelompok Bermain), and kindergarten or TK (Taman Kanak-kanak). Each facility implements inclusive program where children with special needs are taught in the same class of those of regular students. PAUD Inklusi Saymara is organized in Holistic Integrative manner, which means integrating programs of education, care, health and nutrition, parenting, and child protection. Educational programs are carried out through learning performed using a central learning model. This model means the systematizing of learning through playing in circles and certain centers such as centers of faith and piety, preparation centers, centers of natural materials, arts and cultural centers, beam centers, and role play centers. Through this education model, teachers stimulate children's growth and development as well as foster their interests including reading interest 
to familiarize them with literacy culture. The programs implemented at PAUD Inklusi Saymara as the efforts to establish literacy culture for children at early age are:

\section{a. Program "one day one story"}

Program "one day one story" is a program implemented by PAUD Inklusi Saymara, in which teacher will ready story to children once a day. There are some techniques in storytelling adapted by teachers at PAUD Inklusi Saymara, including storytelling with books, storytelling with pictured cards, series of drawings, or hand puppets and finger puppets. Storytelling is advantageous for children to develop their language and communication skills, develop their fantasy and imagination, improve spirituality, values, and norms, train their concentration, develop characters, and foster their reading interest so that they will acquire literacy culture at early age. Storytelling is important to establish literacy culture in children because children's basic reading skills will be stronger through simple storytelling if compared to spelling letters. Therefore, "one day one story" is implemented for these purposed and to implant good characters in children through moral message included within the story they are told.

Huck, et al. (1987) and Cullinan (1989:1223) in Santoso (2008) mentioned that when children read or dibacakan literatures including story book, it will help their cognitive development, language development, and their moral and social development. On different parts, Wright (in Hafid, 2002) stated that story could help children understand their world and will talk about it to other parties. Stories could motivate, enrich their vocabularies, and they are easy to acquire. Therefore, reading story is expected to improve children's potential in appreciating literary works including to encourage them in having reading interest.

In accordance to Piaget Piaget's theory stating that children of 2 to 7 years old are in pre-operational stage, in which their mindset still depends on the assistance of objects or concrete occurrences that they see or experience. Related to this thing, books especially picture books will help children to materialize learning through story appreciation.

The storytelling method on "one day one story" program implemented at PAUD Inklusi Saymara to inspire reading interest on children at early age is in accordance to a research conducted by Santoso (2008) that children at early education have higher respond towards pictures in reading and writing process. Picture books motivates them to study more. Proper picture books will help children as they try to understand and enrich experience through story. The purposes of picture books in this case are to encourage them to appreciate and love books. Furthermore, good picture books could also entertain them and give them aesthetic experience.

b. The learning of reading interest based on library

An education institution is not complete without a library. Therefore, PAUD Inklusi Saymara also has library to support reading interest and foster literacy culture for its students. In addition to the main school 


\section{ECRJ}

library, every class is also equipped with mini library consisted of storybooks, children activity books, and so on, based on the needs of that class, especially to support the central learning activity and "One Day One Story" program. The visit to the main library is scheduled for each class group, in which at least students will visit the library once a week according to the schedule. There are many activities during the visit to library such as Story Telling, independent reading, educational films watching, and many others that mainly focus on familiarizing children with books in order to foster literacy culture from early age. Besides scheduled visit, students are also allowed to visit the library during recess or while they wait for their parents.

Bafadal, as cited by Junaeti in Membumikan Gerakan Literasi di Sekolah dengan editor Mursyid (2016), mentioned that school library is the systematically organized collection of references, both in the form of books and non-book materials contained in a room so that it will help students and teachers during their learning process. Library has central role in fostering and developing reading awareness. Reading cannot be separated from the availability of enough reading materials both in quality and quantity. Based on this opinion, PAUD Inklusi Saymara attempts to utilize library as the facility to develop reading interest. Even though in general, the management of library at PAUD Inklusi Saymara is not maximally done as in elementary or junior high school, the school does try to improve the school management including the library facility to realize a more comfortable nuance at school so that reading interest will naturally flourish on all school members.

c. Stimulation of reading and writing development through playing method

In order to develop literacy culture at early age, it should be supported with the children's ability to read and write. PAUD Inklusi Saymara is committed to provide suitable stimulation to develop children's reading and writing skills through playing method. Playing is the most suitable method to stimulate children's growth including in reading and write. While playing, children's sensory organs work actively. They will capture all information, and will be conveyed to the brain as receptor, in which the brain cells will actively develop to form wiring. Similarly, the stimulation to read and write should be done through playing to reinforce the activity of brain cells. Stimulation to read and write on children at PAUD Inklusi Saymara is performed in several methods including activities at preparation center such as matching pictures of certain object and its name, scribbling, playing letter cards, and so on. Furthermore, reading lesson is also performed at private class with children by using books such as Anak Islam Suka Membaca and Anak Islam Terampil Menulis. Private reading class is also conducted after the main class where the children are relaxing and without coercion.

According to the reading stages explained above, the reading development of 4-6 years old children occurs in five stages; they are (1) magical stage, (2) self-concept stage, (3) bridging reading stage, (4) sake-off reader stage, and (5) independent reader stage. 


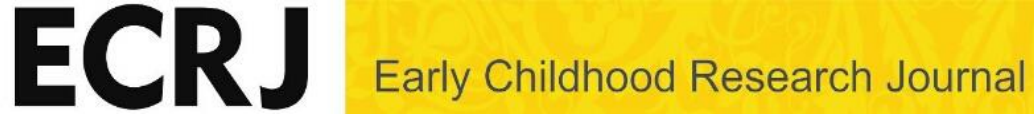

Hence, this research considers that the implementation of reading lesson at PAUD Inklusi Saymara refers to this theory where the children is familiarized with books, pretend to read books, appreciate reading materials, and read pictures during the independent reading or storytelling by the teachers. The stage of introducing reading materials through private lesson by reading AISM book without coercion, and after this stage, it is expected that the children will arrive to independent reading.

Furthermore, during the observation writing lesson at PAUD Inklusi Saymara is according to writing stages by Brewer, cited in Dhieni (2006), as follows:

Scribble Stage or stage of making scribbles. On this stage, children begin to create signs or writings with pen or pencil. They start to learn written language and how to use writing materials during this stage

Linier Repetitive Stage or stâge of making repetitive lines. On this stage, children trace the horizontal form of writing.

Random Letter Stage or stage of writing random words. On this stage, children learn various shapes that are a form of words and repeat these words or sentences.

Letter Name Writing or Phonetic Writing is the stage of writing names. On this stage, children start to compile and connect words and its sound simultaneously.

Writing lesson begin when the children are at daycare by strengthening fine motor coordination through several activities such as shredding and squeezing paper, and then the process is continued to playgroup of 3-4 year old by holding pencil on scribbling stage using various media such as pencil, crayon, brush, saffron, and so on. During their 4-5 years old or A group, the children are taught how to write random letters, words, or sentences, even though they are not perfect. After that, children are taught to write names, which is by connecting words and its sound.

d. Outing Class to bookstores

Outing Class activity at PAUD Saymara is a routine activity organized once in a semester. This activity aims to give children the experience about their surrounding environment and as the main understanding of the developed theme. One of the outing class activities at PAUD Inklusi Saymara is the visit to the bookstore. The visit to bookstore is to introduce and familiarize books for children and to grow their literacy culture at early age. Today, going to the mall or other popular places is considered as more trendy compared to going to a bookstore. This program expects children to be familiar with visiting a bookstore and this visit is an educative fun activity.

Through the program to strengthen literacy culture implemented at PAUD Inklusi Saymara, the reading interest of children at early age could improve well. Like carving, early childhood education is like carving on stone, it will remain intact until they mature. For the next 20 years, the future of Indonesia will depend on how we teach them including by fostering their reading interest. With these efforts, we hope literacy culture could be realized, starting from family unit, continued to school, and will realize literacy culture in the community. 


\section{ECRJ}

\section{CONCLUSION}

One method to enhance the civilization of a region or a country is through education. High quality education becomes an important asset in the midst of increasingly uncompromising global competition. One effort to attain quality education is through improving literacy culture (reading and writing). Most learning process depends on the ability and awareness of literacy. Literacy culture strongly attached to young generation will influence success both in education level and in community.

Building a culture is similar to fostering habits, and improving literacy culture is not as easy as falling off of a log. Literacy culture cannot be established instantly as it needs habits developed during early childhood. Reading culture should be started at home. Family is the very first environment experienced by children and it is the beginning of their habits. In addition to home, improving reading interest should be maintained at school. School is the perfect environment for this and highly influential for furthering children's reading interest. School literacy movement is a participative effort or activity by involving all school members (students, teachers, principals, staffs, school supervisor, school committee, and parents), academicians, publishers, mass media, and community (public figure representing exemplary behavior, business, etc.).

Litreacy culture program at school can be started from Pendidikan Anak Usia Dini or Early Childhood Education such as implemented by PAUD Inklusi Saymara. Literacy culture strengthening program is expected to improve children's reading interest at early age. Other programs that can be implemented include "one day one story" program, in which every day teachers will read story and do storytelling activities for the children via various media. Storytelling activities are very important to enhance literacy culture on children because children's early reading ability is through reading/storytelling of simple stories rather than spelling letters. Reading stories with fascinating manners provides an understanding that reading books can be interesting and it will stimulate children's reading interest. The second program is strengthening reading interest based on library. Library has central role in fostering and growing reading awareness. Reading activity cannot be separated from the existence and availability of good reading materials both in quality and quantity. Reading materials available in the library should be interesting and is adjusted according to the characteristics of children's at early age. The third program is stimulating reading and writing activities by playing. Playing is the perfect medium to stimulate children's ability of writing and reading. While playing, children's five senses work actively. Information captured through children's senses is resumed to the brain as stimulation, in which the brain cells actively develop to form wiring. The stimulation of reading and writing skills development at di PAUD Inklusi Saymara Kartasura is according to the development phases of reading and writing on children at 4-6 years old. The fourth program is outing class to bookstore. Visit to 
bookstore aims to introduce and familiarize books towards children and to foster literacy culture from early age.

Through the programs of literacy culture strengthening at PAUD Inklusi Saymara, children's reading interest could be developed well. With this programs, we hope that literacy culture will start from family, continued during school: therefore, literacy culture will be realized in society.

\section{REFERENCES}

Dhieni, N. (2006). Metode pengembangan bahasa. Jakarta: Universitas Terbuka

Ghoni, M. D. (2017). Metodologi penelitian kualitatif. Yogyakarta: Arrus Media

Mursyid, M. (2016). Membumikan gerakan literasi di sekolah. Yogyakarta: Lembaga Ladang Kata.

Moleong, L. J. (2000). Metodologi penelitian kualitatif. Bandung: PT Remaja Rosdakarya.

Musfiroh, T., \& Beniati, L. (2016). Konstruk kompetensi literasi untuk siswa sekolah dasar, LITERA, Volume 15(1).

Permatasari, A. (2015). Membangun kualitas bangsa dengan budaya literasi. Proceeding at Seminar Nasional Bulan Bahasa UNIB.

Republika, 12 September 2015

Santoso, H. (2008). Membangun minat baca anak usia dini melalui penyediaan buku bergambar. Article in Pustakawan Perpustakaan UM.

Suragangga, I. M. N. (2017). Mendidik lewat literasi untuk pendidikan berkualitas. Jurnal Penjaminan Mutu Lembaga
Penjaminan Mutu Institut Hindu Dharma Negeri Denpasar 3(2). 